\title{
UNCERTAINTIES ON THE OUTDOOR CHARACTERIZATION OF PV MODULES AND THE CALIBRATION OF REFERENCE MODULES
}

José Manuel Carrillo*, Francisco Martínez-Moreno, Celena Lorenzo, Eduardo Lorenzo

Instituto de Energía Solar, ETSIS Telecomunicación, Universidad Politécnica de Madrid, 28031 Madrid, Spain

jm.carrillo@ies.upm.es

\begin{abstract}
This paper presents the IES-UPM experience in the outdoor characterization of PV modules. On days with clear sky conditions, a rather simple device consisting of a thermally-insulated wooden box allows the STC characteristics and the thermal coefficients of PV modules to be measured with low expanded uncertainty $( \pm 1.87 \%$ in power $(k=2))$. Particular attention has been paid to the calibration of the reference cell used for measuring the irradiance and making our measurements traceable to the International System of Units (S.I.). Furthermore, the uncertainty on the irradiance and module temperature measured by the reference PV modules calibrated with the help of this box has also been analyzed in relation to the angle of incidence of the direct irradiance. We think this experience is particularly interesting for local measurements in many countries currently incorporating PV plants in their electric grid, but lacking in specialized PV laboratories equipped with expensive solar simulators.
\end{abstract}

Keywords: Uncertainty, I-V curve, PV module, Outdoor measurements, Reference module, Characterization at Standard Test Conditions.

\section{Introduction}

Indoor PV module characterization using Solar Simulators is becoming more common than outdoor characterization at real sun. Solar simulators offer independence with respect to time and weather conditions. This represents an obvious advantage for both PV module manufacturers, who must test their products at the same production rate, and for specialized laboratories located in places which often have cloudy or polluted skies. For this reason, a solar-simulator industry offering well normalized products (IEC:60904-9, 2007; "Solar simulators for PV modules," 2010, "Solar simulators for PV modules includes new types of testers based on LED lamps," 2011) has been developed for years and many relevant players in the current field of PV now have this equipment. This has contributed to extending the common believe that highly-accurate PV measurements are easily taken by solar simulators. A symptom of this belief is the recent supply of mobile solar simulators (Coello et al., 2014; "Mobile PV Testcenter. Intertek," 2016, "Mobile quality control. Sun Energy Europe," 2012, "PV MobiLAB. Kirchner Solar Group," 2012; Navarrete et al., 2015) for the indoor testing of PV modules on the PV plant sites. 
A main disadvantage of solar simulators is its price, which can easily exceed $€ 150,000$ for an AAA type. This cost is large enough to dissuade many possible PV practitioners (universities, engineers, etc.) from trying to measure PV modules accurately, as required under due diligence for controlling the delivered power of PV modules supplies or for PV reference-module calibration. This is particularly annoying in many countries currently incorporating PV plants into their electric gird, but which lack specialized PV laboratories -Bolivia, Cape Verde, Equator, Kenya, Senegal, etc. are just a few examples. However, most of these countries often enjoy clear skies that represent an appealing alternative to accurate outdoor PV module testing.

The outdoor measurement of PV electrical performance has been reported by widely-recognized laboratories, such as the Arizona State University`s Photovoltaic Test Laboratory (Whitfield and Osterwald, 2001), The European Solar Test Installation, ESTI, at the European Commission's Joint Research Center (Müllejans et al., 2009) and the Florida Solar Energy Center (Atmaram, 2006). All of them are dedicated to transferring I-V curves gathered under outdoor conditions to Standard Test Conditions, STC. All the corresponding analyses highlight that the major relative contribution to the uncertainty of the module power rating results comes from the calibration of the reference device (module or cell) used for measuring incident irradiance. In order to reduce the I-V curve corrections in accordance with IEC 60891, 2009, the irradiance is typically restricted to the range between 800 and $1100 \mathrm{~W} / \mathrm{m}^{2}$. Temperature-related elements of uncertainty derive from back skin -to-cell temperature deviation and from the non-uniformity of the temperature within a module. The outdoor set-up of the ESTI consists of a thermally-insulated box with a sliding door. The PV module is placed inside the box and the I-V curves are recorded just after opening the door, when the temperature of the PV module is still close to the ambient temperature (which, in turn, is usually relatively close to the reference temperature of $25^{\circ} \mathrm{C}$ ). Interestingly, the authors of an uncertainty comparison between ESTI available indoor (solar simulator) and outdoor methods conclude that "the outdoor set-up taking advantage of the uniformity of natural sunlight is preferred. As the temperature uncertainty is the major contribution to the overall uncertainty for the latter, the implementation of a temperature control system for the box (to stabilize the module at the desired temperature of $25^{\circ} \mathrm{C}$ ) in which the module is mounted would be beneficial" (Müllejans et al., 2009). The superiority of natural sunlight for PV measurements has also been highlighted by other authors (Keogh and Blakers, 2004). In fact, several primary calibration techniques use it (Müllejans et al., 2005b).

This paper reports on the IES-UPM experience in the outdoor testing of PV modules, using a "Solar Box", a rather simple home-made device simply consisting of a thermally-insulated box coupled to a temperature control system. The latter is controlled using standard air conditioning, to achieve the desired temperature, and internal fans to keep the temperature inside the box uniform. Measurements of the STC power are complemented by measuring the temperature coefficients and irradiance coefficients, the latter, without the help of the "Solar Box". Since 2013, we have characterized about 400 PV modules, many of them to be used as reference modules to measure the effective irradiance, $G_{\text {ef, }}$ and the solar cell temperature, $T_{C}$, as quality assurance 
procedures for large commercial crystalline silicon PV plants (Martínez-Moreno and Lorenzo, 2015; Martínez-Moreno and Tyutyundzhiev, 2015).

The instrumentation, measurement procedures and associated uncertainties are described. Moreover, attention is also paid to the uncertainties on $G_{\text {ef }}$ and $T_{\mathrm{C}}$ values measured with these reference PV modules.

\section{PV module characterization procedure}

The Standard Test Conditions, STC, and temperature coefficients are characterized in terms of a uniform and perpendicular illumination of $1000 \mathrm{~W} / \mathrm{m}^{2}$ irradiance and AM1.5 spectrum, and a uniform solar cell temperature of $25^{\circ} \mathrm{C}$. Fig. 1 shows the simple device, called the "Solar Box", that we have made to help achieving these conditions under the real sun. It is made up of a $2.10 \times 1.80 \times 0.33 \mathrm{~m}$ (length $\mathrm{x}$ width $\mathrm{x}$ height - internal dimensions) thermally-insulated wooden box with polystyrene and equipped with a standard air-conditioning system. The box is mounted on a metallic structure that can be manually positioned in both azimuth and tilt. A working reference solar cell, coplanar but external to the box, provides a first approximation to the incident irradiance while the box is still closed.

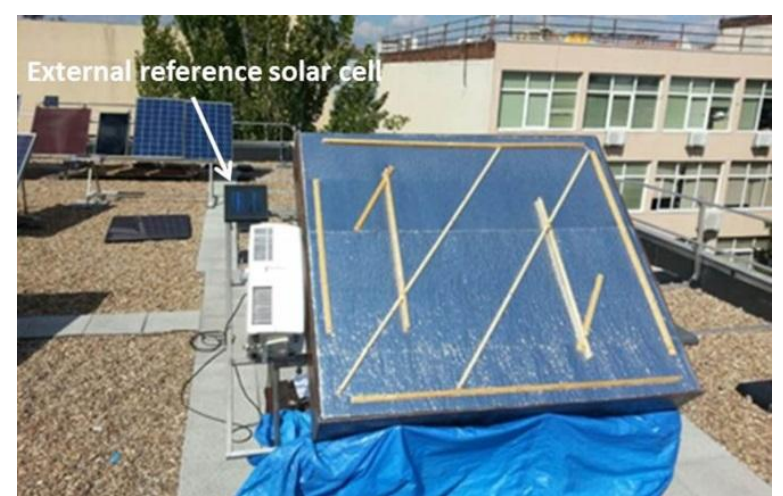

(a)

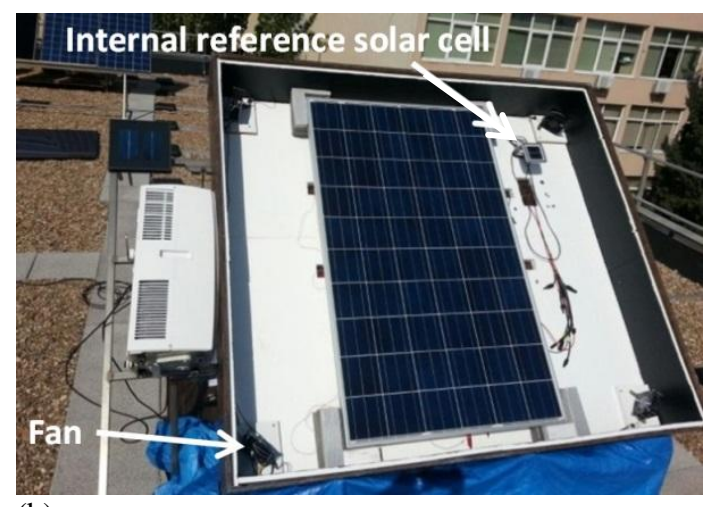

(b)

Fig. 1.Solar Box developed by IES-UPM used for testing PV modules outdoors. (a) Solar Box covered. (b) Solar Box opened. The figure shows the external and internal reference solar cells, the four fans to homogenize the temperature inside the box before it is opened, the air conditioning and the module inside, prepared to be measured at STC.

The PV module is placed inside the box in such a way that the air-gap between the PV module surfaces (back-sheet and front-glass) and the inner box surfaces is about $15 \mathrm{~cm}$, which ensures easy air circulation (Gan, 2009). Then, the box is oriented until this cell indicates an irradiance value close to $1000 \mathrm{~W} / \mathrm{m}^{2}$ (according to our experience, $\pm 5 \%$, which is easy to obtain, suffices). Meanwhile, the air conditioning system maintains an inside temperature which is slightly lower than $25^{\circ} \mathrm{C}$ (quite often by cooling it down). Four fans located in the corners of the internal box help to homogenize the temperature (Huang et al., 2011). Then, the front cover of the box is removed and $25 \mathrm{I}-\mathrm{V}$ curves, equally spaced on time, are obtained throughout the PV module's natural 
heating process, which takes about 20 minutes. 9 PT1000 sensors glued to the back sheet of the PV module measure the temperature of the solar cell. The effective irradiance is accurately measured simultaneously by means of a carefully calibrated reference cell (Annex) placed inside the box. This reference cell is a monocrystalline silicon sensor, short-circuited through a high stability resistor, in such a way that the cell provides a voltage signal (which is recalibrated annually). The I-V curves are obtained by means of a home-made capacitive load (Muñoz et al., 2015) with a capacitor large enough to assure a charging time of more than $20 \mathrm{~ms}$. Prior to tracing the curve, the capacitor is negatively pre-charged to ensure the short-circuit crossing. The connections of the PV module to this electronic load are made with four-point Kelvin probes. The incident irradiance, the voltage across the PV module (measured with two of the Kelvin probes) and its current (measured with the other two Kelvin probes as a voltage across a $150 \mathrm{mV} / 10 \mathrm{~A}$, or $15 \mathrm{~m} \Omega$, calibrated resistor) are acquired simultaneously through a differential four isolated channel digital storage oscilloscope with a sampling frequency of 5MS/s and 12 bit digitization. Typically, a total of $10 \mathrm{k} \mathrm{I-V}$ points are acquired for each I-V curve. The data are transferred via USB interface to a PC when the measurement of the I-V curve is finished. Prior to their treatment, the data are digitally filtered (Caamaño et al., 1999) by selecting the first 40 coefficients of the Discrete Fourier Transform for both sequences of I and V. Data from the PT sensors are read synchronously using a datalogger (20-bit digitization). The average of the corresponding 9 values, once corrected by $+3^{\circ} \mathrm{C}$ to compensate the drop in cell-to-back-skin temperature (King et al., 1998, 1997; Whitfield and Osterwald, 2001) is considered to be the true PV module temperature. Finally, the I-V curves are characterized in terms of power, voltage and current at the maximum power point, $P_{M P P}, V_{M P P}$ and $I_{M P P}$, respectively, and of the short-circuit current, $I_{S C}$, and open circuit voltage, $V_{O C}$. When these variables appear with the superscript ${ }^{*}$, they refer to STC. Strictly speaking, such $+3^{\circ} \mathrm{C}$ temperature correction is only valid in thermal equilibrium, so that its validity in the situation after the lid has been lifted and the module is warming up can be questioned. However, applying such correction leads to $V_{O C}^{*}$ values that agree well (better than $0.4 \%$, as we will see later) with the values measured at pulsed solar simulators which are free of the drop in cell-toback-skin temperature effect. That is the main reason leading us to keep the correction even in that situation.

In order to minimize corrections and uncertainty, the measurements are validated just if $G_{\text {ef }} \geq 900$ $\mathrm{W} / \mathrm{m}^{2}$ and the temperature between the hottest and the coldest point of the PV module (as given by the 9 PT1000) differ by less than $3^{\circ} \mathrm{C}$ at the beginning of the procedure (when testing the STC characteristics) and by less than $7^{\circ} \mathrm{C}$ throughout the rest of the process (when testing the temperature coefficients). That makes our measurements comply with IEC:60904-1, 2006; IEC:60904-4, 2011 and IEC 60891, 2009. Corrections to STC are made in accordance with IEC 60891. In fact, our conditions are even more restrictive than that demanded by the norm. For example, IEC 60904-4 requires $G_{\text {ef }} \geq 800 \mathrm{~W} / \mathrm{m}^{2}$ and we impose $G_{\text {ef }} \geq 900 \mathrm{~W} / \mathrm{m}^{2}$; IEC 60891 requires the temperature to be measured at 4 positions, however we measure it at 9 positions. As the tested PV modules and the work reference cell are of equivalent technology (c-Si), possible spectral corrections are completely disregarded. Measurements are performed just on clear days, so that the irradiance keeps essentially constant along the 20 minutes process. 
Finally, in order to make further research possible, collateral information is also recorded: barometric pressure provided by a meteorological station on the measurement site, as is the spectral related data (Aerosol Optical Thickness, water vapor and Angstrom parameter ("AERONET," 2006)).It is worth mentioning that in Madrid we have about 180 sunny and totally clear days per year, and close to 75 partially cloudy days that still allow good measurements to be taken.

\subsection{Rated power}

Fig. 2 shows a representative I-V curve obtained at the beginning of the process and close to STC. The PV module is an Atersa A245P, with 60 polycrystalline-Si cells and a nominal power of $245 \mathrm{~W}_{\mathrm{p}}$, and it has been stabilized after $60 \mathrm{kWh} / \mathrm{m}^{2}$ of exposure to the Sun. The particular measurement conditions are $G_{\text {ef }}=1003 \mathrm{~W} / \mathrm{m}^{2}$ and $T_{\mathrm{C}}=24.4^{\circ} \mathrm{C}$. Table 1 details the values of the characteristic parameters for both the recorded and the corrected STC I-V curves. The low impact of this correction, about $0.6 \%$ in $P_{M P P}^{*}$, is noticeable. Later we will see that the finally assigned $P_{M P P}^{*}$ value, resulting from several measurements performed along a year, is $237.4 \mathrm{~W}$. The slight difference between individual and average results can be understood as an indication of low uncertainty.

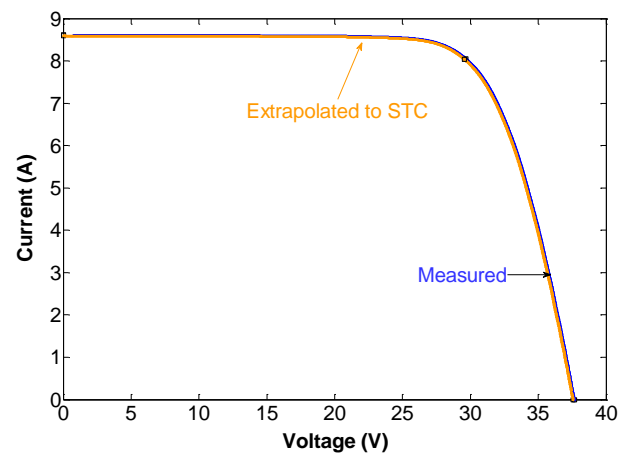

Fig. 2. Current versus voltage, I-V, curve measured almost at STC.

\begin{tabular}{|ccccccc|}
\hline $\begin{array}{c}\text { Electrical } \\
\text { parameters }\end{array}$ & $\boldsymbol{I}_{\text {SC }}(\mathrm{A})$ & $\boldsymbol{V}_{\text {OC }}(\mathbf{V})$ & $\boldsymbol{I}_{\text {MPP }}(\mathrm{A})$ & $\boldsymbol{V}_{\text {MPP }}(\mathrm{V})$ & $\boldsymbol{P}_{\text {MPP }}(\mathbf{W})$ & $\boldsymbol{F F}$ \\
\hline Measured & 8.61 & 37.66 & 8.05 & 29.66 & 239.03 & 0.737 \\
Extrapolated to STC & 8.59 & 37.58 & 8.04 & 29.56 & 237.65 & 0.736 \\
\hline Difference (\%) & 0.23 & -0.21 & 0.12 & 0.34 & 0.58 & 0.14 \\
\hline
\end{tabular}

Table 1. Values of the measured and extrapolated to STC characteristics parameters.

\subsection{Temperature coefficients}


Fig. 3 shows the evolution of the characteristics of the PV module versus the temperature for the same module as Fig. 2. Their slope determines the value of the corresponding temperature coefficients:

$$
\alpha=\frac{1}{I_{S C}^{*}} \frac{d I_{S C}}{d T_{C}} ; \beta=\frac{1}{V_{O C}^{*}} \frac{d V_{O C}}{d T_{C}} ; \gamma=\frac{1}{P_{M P P}^{*}} \frac{d P_{M P P}}{d T_{C}}
$$

Furthermore, the temperature coefficient of the $F F(\delta)$ can be obtained by:

$$
\delta=\frac{1}{F F^{*}} \frac{d F F}{d T_{C}}=\gamma-(\alpha+\beta)
$$

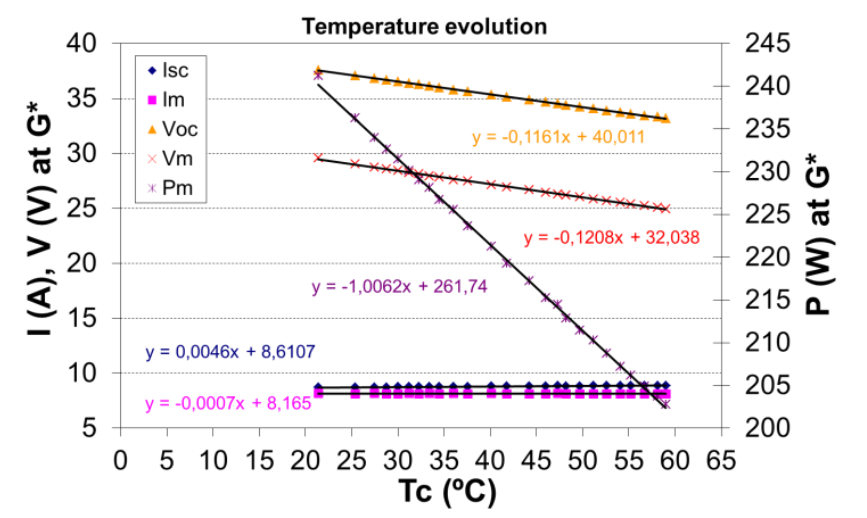

Fig. 3. PV module characteristics versus module temperature, throughout the measuring process.

For a $T_{\mathrm{C}}$ ranging from 22 to $59^{\circ} \mathrm{C}$, the results of the coefficients are: $\alpha=0.053 \% /{ }^{\circ} \mathrm{C}, b=-0.31 \% /{ }^{\circ} \mathrm{C}$, $\gamma=-0.43 \% /{ }^{\circ} \mathrm{C}$ and $\delta=-0.17 \% /{ }^{\circ} \mathrm{C}$. iError! No se encuentra el origen de la referencia. shows the evolution time of $T_{\mathrm{C}}$ and the corresponding non-uniformity throughout the heating process. It is worth mentioning that we have performed some measurements by taking the additional precaution of covering the back sheet of the module with a thermally-insulating foil. As expected, the final stabilized module temperature has increased from about 60 to $70^{\circ} \mathrm{C}$. However, we did not observe significant differences in the resulting values of the temperature coefficients. Hence, we decided to disregard this precaution in our standard procedure.

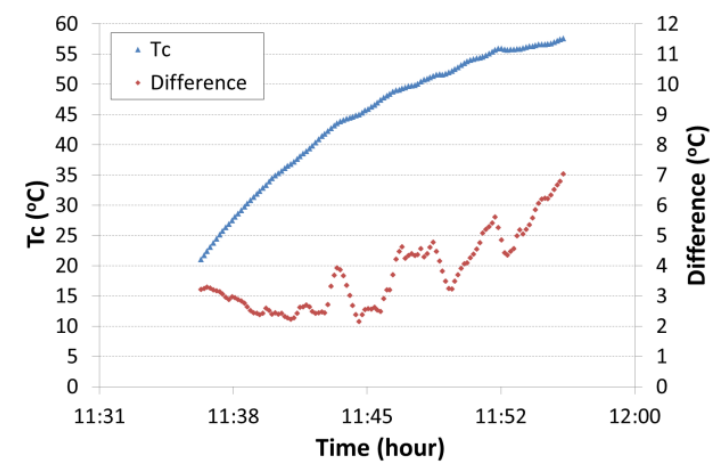

(a)

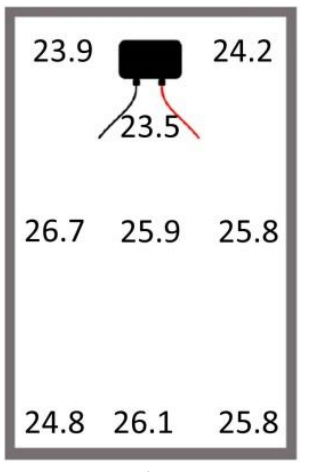

(b)

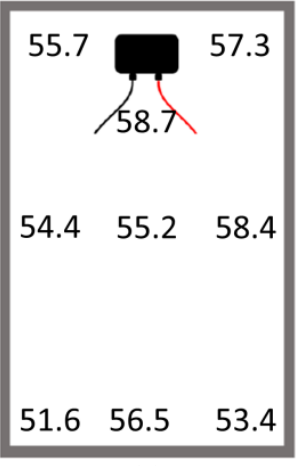

(c)

Fig. 4. (a) Evolution of the temperature of the module $\left(T_{\mathrm{C}}\right)$ and evolution of the maximum temperature difference among the 9 PT1000 throughout the measurement process. (b) Temperatures of the 9 PT1000 at the start of the process. (c) Temperatures of the 9 PT1000 at the end of the process. 


\subsection{Irradiance coefficients}

A critical review (De la Parra et al., 2017) of different available models for PV efficiency led us to conclude that only three independent parameters, one for temperature and two for irradiance, suffice to describe the PV performance of PV modules accurately in relative terms to STC. The oldest model complying with this idea was proposed fourteen years ago (Willians et al., 2003) and is given by:

$$
\eta^{\prime}=\left(1+\gamma T^{\prime}\right)\left(a_{1}+a_{2} G^{\prime}+a_{3} \ln G^{\prime}\right)
$$

where

$$
\eta^{\prime}=\frac{\eta}{\eta^{*}} ; \quad G^{\prime}=\frac{G}{G^{*}} \text { and } T^{\prime}=T_{C}-T_{C}^{*}
$$

where $\eta$ is the efficiency of the PV module and $a_{1}, a_{2}$ and $a_{3}$ are empirically adjusted parameters. The particularization of this equation for STC leads to the condition:

$$
a_{1}+a_{2}=1
$$

Consequently, equation (3) can be rewritten as

$$
\eta^{\prime}=\left(1+\gamma T^{\prime}\right)\left(a_{1}+\left(1-a_{1}\right) G^{\prime}+a_{3} \ln G^{\prime}\right)
$$

This requires only three parameters, one for temperature and two for irradiance. As the PV module concerned has been characterized first in terms of $I_{S C}^{*}, V_{O C}^{*}, P_{M P P}^{*}, \alpha, \beta$ and $\gamma$, we can derive the two irradiance parameters from just two I-V curves obtained at two irradiances other than $G^{*}$. This time we can manage without the Solar Box. We simply obtain $4 \mathrm{I-V}$ curves at irradiances close to $200,400,600$ and $800 \mathrm{~W} / \mathrm{m}^{2}$, irrespective of the temperature of the module. Four curves instead of only two are enough for a better adjustment. Each curve is treated as follows:

First, $G_{\mathrm{ef}}$ and $T_{\mathrm{C}}$ are derived from $I_{\mathrm{SC}}$ and $V_{\mathrm{OC}}$ by:

$$
\begin{gathered}
G_{e f}=\frac{I_{S C}}{I_{S C}^{*}} G^{*}\left[1+\alpha\left(T_{C}-T_{C}^{*}\right)\right]^{-1} \\
V_{O C}^{C}=V_{O C}+N_{S} \frac{m k}{q}\left(T_{C}+T_{0}\right) \cdot \ln \frac{G_{e f}}{G^{*}} \\
T_{C}=T_{C}^{*}+\left(\frac{V_{O C}^{C}}{V_{O C}^{*}}-1\right) / \beta
\end{gathered}
$$

where $N_{\mathrm{S}}$ is the number of solar cells associated in series, $k$ is the Boltzmann constant $\left(1.38 \times 10^{-}\right.$ $\left.{ }^{23} \mathrm{~J} \cdot \mathrm{K}^{-1}\right), q$ is the elementary charge $\left(1.6 \times 10^{-19} \mathrm{C}\right), m$ is the ideality factor of the diode $(m=1.3$ is a reasonable choice for $\mathrm{C}-\mathrm{Si}), T_{\mathrm{C}}$ is expressed in ${ }^{\circ} \mathrm{C}$ and $T_{0}$ is the absolute temperature at $0^{\circ} \mathrm{C}$ 
(273.15K) and $V_{O C}^{C}$ can be understood as the open circuit voltage corrected in irradiance. Note that equations (7) to (9) form a non-linear equation system with no analytical solution. However, it is easily solved numerically through an iterative process starting with $T_{\mathrm{C}}=T_{\mathrm{C}}{ }^{*}$. Typically, two iterations lead to errors of well below $1 \%$. It must be stressed that effective incident irradiance is directly determined from the $I_{\text {sc }}$ itself of the PV module tested, once the corresponding STC value has been measured in a previous step. It has been referred that this leads to less uncertainty than using a dedicated irradiance sensor (Campanelli and Osterwald, 2016) - this is also our experience.

Second, the relative efficiency corrected to $\mathrm{T}_{\mathrm{C}}{ }^{*}, \eta_{G}^{\prime}$, is calculated as:

$$
\eta_{G}^{\prime}=\frac{P_{M P P}}{P^{*}{ }_{M P P}} \frac{1}{1+\gamma T^{\prime}} \frac{1}{G^{\prime}}
$$

and the values of $a_{1}, a_{2}$ and $a_{3}$ are determined from the best fit of the second term in equation (3) to the four $\eta_{G}^{\prime}$ resulting values. Finally, $\eta_{0.6}^{\prime}$ and $\eta_{0.2}^{\prime}$ are calculated and given as reference values, which allows the parameters of any PV efficiency versus irradiance model to be adjusted (Table 2 and Fig. 5 presents the measurements performed on the same PV module that on section 2.1 and 2.2).

\begin{tabular}{|c|c|c|c|c|c|}
\hline \multicolumn{3}{|c|}{ Measurements } & \multirow{2}{*}{$G_{\text {ef }}\left(\mathrm{W} / \mathrm{m}^{2}\right)$} & \multirow{2}{*}{$T_{\mathrm{C}}\left({ }^{\circ} \mathrm{C}\right)$} & \multirow{2}{*}{$\eta_{G}^{\prime}$} \\
\hline$I_{\mathrm{SC}}(\mathrm{A})$ & $V_{\text {oc }}(\mathrm{V})$ & $P_{\text {MPP }}(W)$ & & & \\
\hline 8.61 & 37.53 & 237.4 & 1000 & 25 & 1 \\
\hline 1.80 & 34.15 & 45.0 & 190 & 12.0 & 0.946 \\
\hline 3.52 & 35.47 & 90.7 & 370 & 15.6 & 0.994 \\
\hline 5.26 & 36.25 & 140.6 & 566 & 19.5 & 1.022 \\
\hline 6.99 & 36.77 & 189.1 & 780 & 22.7 & 1.012 \\
\hline \multicolumn{6}{|c|}{ Model parameter } \\
\hline \multicolumn{2}{|c|}{$a_{1}=1.22$} & \multicolumn{2}{|c|}{$a_{2}=-0.22$} & \multicolumn{2}{|c|}{$a_{3}=0.14$} \\
\hline \multicolumn{6}{|c|}{ Reference values } \\
\hline \multicolumn{3}{|c|}{$\eta_{0.2}^{\prime}=0.95$} & $\eta_{0.6}^{\prime}$ & & \\
\hline
\end{tabular}

Table 2. Measurements at 4 different operating conditions and derived efficiency versus irradiance model parameters.

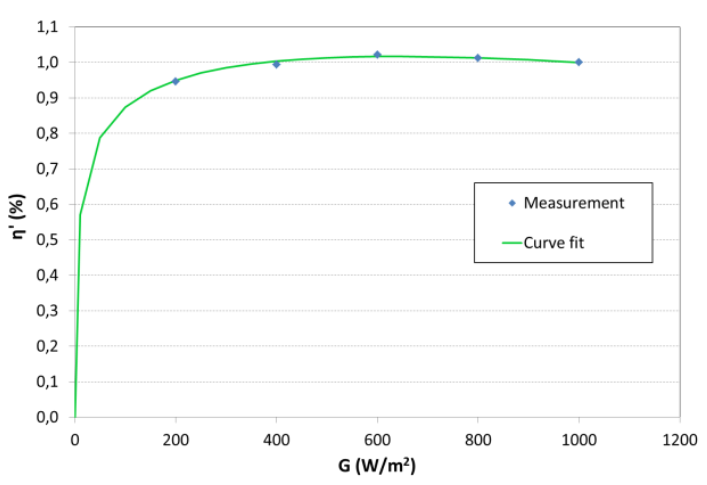

Fig. 5. Relative efficiency, $\eta$ ', versus irradiance, $G$, observed values (corrected to $25^{\circ} \mathrm{C}$ ) and fitted curve. 


\section{Uncertainty on the PV module characteristics}

\subsection{Reference cell}

Table 3 presents the uncertainty components identified in this work. Following the analysis and terminology contained in the Guide to the Expression of Uncertainty in Measurements (ISO/IECGuide98-3, 2008), it is indicated whether they are considered as Type A (whose uncertainty is estimated as the standard deviation of a series of repeated determinations) or Type $B$ (whose uncertainty is calculated from the instrument's accuracy and calibration characteristics). Table 3 also indicates the corresponding affected parameter.

As recognized by other authors, the main contribution to uncertainty comes from the reference cell used for measuring irradiance and linking the traceability of our calibrations to the International System of Units (S.I.). This is why we have paid particular attention to the calibration of this device. By crossing different mutually independent calibrations, we have reached a standard uncertainty of $\pm 0.67 \%$, which is close to the middle value between the corresponding uncertainties on a primary reference cell $( \pm 0.12 \%$ (Müllejans et al., 2015)) and the typical secondary one $( \pm 2 \%)$. The different external calibrations and the uncertainty estimation procedures are described in Appendix.

\begin{tabular}{|llllllll|}
\hline Uncertainty & Component & Type & $\boldsymbol{P}_{\boldsymbol{M P P}}^{*}$ & $\boldsymbol{I}_{\boldsymbol{S C}}^{*}$ & $\boldsymbol{V}_{\boldsymbol{O} \text { C }}^{*}$ & $\begin{array}{l}\text { Temp. } \\
\text { Coeff. }\end{array}$ & $\begin{array}{c}\text { Irrad. } \\
\text { Coeff. }\end{array}$ \\
\hline \multirow{4}{*}{ Irradiance } & Reference cell calibration & $\mathrm{B}$ & $\mathrm{X}$ & $\mathrm{X}$ & & & \\
& Spectral mismatch & $\mathrm{A}$ & $\mathrm{X}$ & $\mathrm{X}$ & & & \\
& Misalignment & $\mathrm{A}$ & $\mathrm{X}$ & $\mathrm{X}$ & & & \\
& Data Acquisition System & $\mathrm{B}$ & $\mathrm{X}$ & $\mathrm{X}$ & & & \\
\hline \multirow{5}{*}{ Temperature } & PT 1000 & $\mathrm{~B}$ & $\mathrm{X}$ & & & & \\
& Non-uniformity & $\mathrm{B}$ & $\mathrm{X}$ & & $\mathrm{X}$ & $\mathrm{X}$ & $\mathrm{X}$ \\
& Backskin-to-cell drop & $\mathrm{B}$ & & & & $\mathrm{X}$ & \\
\hline Electrical & Data Acquisition System & $\mathrm{B}$ & $\mathrm{X}$ & $\mathrm{X}$ & $\mathrm{X}$ & $\mathrm{X}$ & \\
\hline \multirow{3}{*}{ Corrections } & Data Acquisition System & $\mathrm{B}$ & $\mathrm{X}$ & $\mathrm{X}$ & $\mathrm{X}$ & $\mathrm{X}$ & $\mathrm{X}$ \\
& $\mathrm{I}-\mathrm{V}$ curve to STC & $\mathrm{A}$ & $\mathrm{X}$ & $\mathrm{X}$ & $\mathrm{X}$ & & \\
& $T_{\mathrm{C}}$ from $V_{\mathrm{OC}}$ & $\mathrm{B}$ & & & & & $\mathrm{X}$ \\
& $P_{M P P}\left(T_{C}\right)$ to $P_{M P P}\left(T_{C}^{*}\right)$ & $\mathrm{A}$ & & & & & $\mathrm{X}$ \\
\hline
\end{tabular}

Table 3. Uncertainty components identified in this work. It is indicated whether they are considered as Type A or Type B, as are the affected parameter results.

\subsection{Type A uncertainties}

In order to quantify Type A uncertainties, we have periodically characterized a single PV module over a full year and analysed the repeatability of results. The PV module model is the same Atersa $A 245 P$, than in section 2. Over 2014, 15 measurements were taken -approximately one per monthand the PV module was kept in the dark between them. 
Fig. 6a shows the time evolution of the measured $P_{M P P}^{*}$ and

Fig. $6 \mathrm{~b}$, the distribution of residuals with respect to the average value. This can be represented by a mean value, $\overline{P_{M P P}^{*}}=237.4 \mathrm{~W}$, and a standard deviation, $u_{A, P_{M P P}^{*}}=0.31 \%$. This deviation is taken as a proper estimation of the Type $A$ standard uncertainty $(k=1)$. Table 4 extends the exercise to the remaining characteristic parameters.
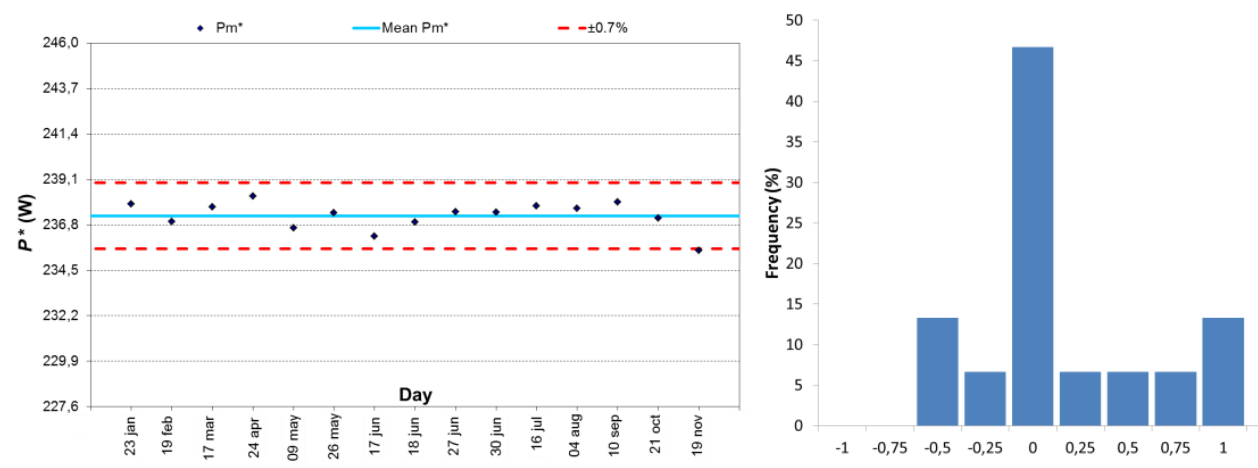

(a)

(b)

Fig. 6. (a) $\boldsymbol{P}_{M P P}^{*}$ of a PV module measured 15 times over a whole year inside the Solar Box. The continuous line represents the mean value of all the measurements and the dotted lines represent a deviation of $0.7 \%$ which includes all the measurements. (b) Distribution of residuals with respect to the average value.

\begin{tabular}{|c|c|c|c|c|c|c|c|c|c|c|}
\hline $\begin{array}{c}P_{M P P}^{*} \\
(W)\end{array}$ & $\begin{array}{c}I_{M P P}^{*} \\
(\mathrm{~A})\end{array}$ & $\begin{array}{l}V_{M P P}^{*} \\
\text { (V) }\end{array}$ & $\begin{array}{l}I_{S C}^{*} \\
(\mathrm{~A})\end{array}$ & $\begin{array}{c}V_{O C}^{*} \\
\text { (V) }\end{array}$ & $\boldsymbol{F F}^{*}$ & $\begin{array}{c}\alpha \\
\left(\% /{ }^{\circ} \mathrm{C}\right)\end{array}$ & $\begin{array}{c}\beta \\
\left(\% /{ }^{\circ} \mathrm{C}\right)\end{array}$ & $\begin{array}{c}V \\
\left(\% /{ }^{\circ} \mathrm{C}\right)\end{array}$ & $\eta_{0.6}^{\prime}$ & $\eta_{0.2}^{\prime}$ \\
\hline 237.4 & 8.06 & 29.47 & 8.61 & 37.53 & 0.734 & 0.06 & -0.32 & -0.43 & 1 & 0.94 \\
\hline$u_{A, P_{M P P}^{*}}^{*}(\%)$ & $u_{A, I_{M P P}^{*}}(\%)$ & $\begin{array}{c}\boldsymbol{u}_{A, V_{M P P}^{*}} \\
(\%)\end{array}$ & $\begin{array}{c}\boldsymbol{u}_{A, I_{S C}^{*}} \\
(\%)\end{array}$ & $\begin{array}{c}\boldsymbol{u}_{A, V_{O C}^{*}} \\
(\%)\end{array}$ & $\begin{array}{c}\boldsymbol{u}_{A, \boldsymbol{F} \boldsymbol{F}^{*}} \\
(\%)\end{array}$ & $\begin{array}{c}\mathbf{u}_{\mathrm{A}, \boldsymbol{\alpha}} \\
\left(\% /{ }^{\circ} \mathrm{C}\right)\end{array}$ & $\begin{array}{c}\mathbf{u}_{\mathrm{A}, \boldsymbol{\beta}} \\
\left(\% /{ }^{\circ} \mathrm{C}\right)\end{array}$ & $\begin{array}{c}\mathbf{u}_{\mathrm{A}, \boldsymbol{\gamma}} \\
\left(\% /{ }^{\circ} \mathrm{C}\right)\end{array}$ & $\boldsymbol{u}_{A, \eta_{0.6}}(\%)$ & $u_{A, \eta_{0.2}}(\%)$ \\
\hline 0.31 & 0.40 & 0.21 & 0.43 & 0.16 & 0.24 & $\begin{array}{c}0.008 \\
(13.33 \%)\end{array}$ & $\begin{array}{c}0.010 \\
(3.13 \%)\end{array}$ & $\begin{array}{c}0.019 \\
(4.41 \%)\end{array}$ & 0.6 & 0.5 \\
\hline
\end{tabular}

Table 4. Average and standard deviation (in \%) of the characteristic parameters measured on a same PV module 15 times over a year.

\subsection{Type B uncertainties}

Table 5 presents the input information (instruments manufacturer specifications, updated calibration certificates, experimental requirements, assumptions, etc.) and the corresponding derived standard uncertainties for Type B components. The shape of the density function for each uncertainty component is generally assumed to be rectangular, so the corresponding standard uncertainty is given by:

$$
u_{B}=\frac{a}{\sqrt{3}}
$$


where $a$ is the interval within which the expected value of the measurement lies. In turns, it is the \pm accuracy typically specified by the instrument manufacturer or the requirement imposed on a given experiment. For example, the PT1000 are specified (manufacturer data) with a tolerance of \pm $0.415^{\circ} \mathrm{C}$. This result translates into a standard uncertainty, $u_{B}^{P T 1000}= \pm 0.240^{\circ} \mathrm{C}$. On similar lines, imposing $3^{\circ} \mathrm{C}$ as the maximum difference between the readings of the 9 PT1000 glued to the back of the PV module is interpreted as a $\pm 1.5^{\circ} \mathrm{C}$ interval and leads to $u_{B}^{\Delta T 3}= \pm 0.866^{\circ} \mathrm{C}$. The drop in temperature between the cells and the PV module back-skin is considered to be $3^{\circ} \mathrm{C}$ with a range of $\pm 1^{\circ} \mathrm{C}$ (King et al., 1998; Whitfield and Osterwald, 2001). D.A.S. is made up of an oscilloscope and a datalogger, which are of 12 and 20 bit digitalization respectively. Measurement ranges are selected in order to obtain signal values larger than half of the full scale.

\begin{tabular}{|c|c|c|}
\hline Component, i & Input information & Standard uncertainty \\
\hline Reference cell calibration & $\begin{array}{l}\text { Crossing different calibrations } \\
\text { (Annex). Normal distribution }\end{array}$ & $u_{B}^{R C C}=0.67 \%$ \\
\hline PT1000 & Accuracy: $\pm 0.415^{\circ} \mathrm{C}$ & $u_{B}^{P T 1000}=0.24^{\circ} \mathrm{C}$ \\
\hline Non-uniform temperature & $\begin{array}{l}\leq 3^{\circ} \mathrm{C} \text { at } \mathrm{STC} \\
\leq 7^{\circ} \mathrm{C} \text { at other than STC }\end{array}$ & $\begin{array}{l}u_{B}^{\Delta T 3}=0.866^{\circ} \mathrm{C} \\
u_{B}^{\Delta T 7}=2.021^{\circ} \mathrm{C}\end{array}$ \\
\hline $\begin{array}{l}\text { Backskin-to-cell drop } \\
\text { temperature }\end{array}$ & $\begin{array}{l}\leq 3^{\circ} \mathrm{C} \\
\text { Range: } \pm 1^{\circ} \mathrm{C}\end{array}$ & $u_{B}^{B T C}=0.577^{\circ} \mathrm{C}$ \\
\hline D.A.S - Oscilloscope & $\begin{array}{l}\text { Accuracy: } \pm 0.2 \% \\
\text { Resolution: } 12 \text { bits digitization }\end{array}$ & 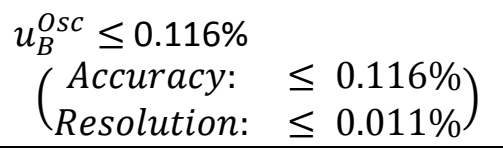 \\
\hline D.A.S - Datalogger & $\begin{array}{l}\text { Accuracy }\left(\mathrm{V}_{\mathrm{DC}}\right): 0.005 \% \text { of } \\
\text { reading }+0.004 \% \text { of range } \\
\text { Accuracy (Temp.): } 0.06^{\circ} \mathrm{C} \\
\text { Resolution: } 20 \text { bits digitization }\end{array}$ & $\begin{array}{l}u_{B}^{\text {Dat,Gef }} \leq 0.005 \% \\
\left(\begin{array}{c}\text { Accuracy: } \leq 0.005 \% \\
\text { Resolution: } \leq 0.00003 \%\end{array}\right) \\
u_{B}^{\text {Dat }, T c \leq 0.035^{\circ} \mathrm{C}} \\
\left(\begin{array}{c}\text { Accuracy: } \leq 0.035^{\circ} \mathrm{C} \\
\text { Resolution: } \leq 0.0001^{\circ} \mathrm{C}\end{array}\right)\end{array}$ \\
\hline Calibrated resistor & Accuracy: $\pm 0.5 \%$ & $u_{B}^{R e s}=0.289 \%$ \\
\hline
\end{tabular}

Table 5. Input information of the instruments and components used in the measurements and the corresponding derived standard uncertainties for the Type B components.

All these uncertainty components are mutually independent. Hence, the resulting combined Type B uncertainties on $G_{\text {ef }}$ and $T_{\mathrm{C}}$ are estimated as:

$u_{B}^{G e f}=\sqrt{\left(u_{B}^{R C C}\right)^{2}+\left(u_{B}^{\text {Dat,Gef }}\right)^{2}}=\sqrt{(0.67)^{2}+(0.005)^{2}}=0.67 \%$ 
$u_{B}^{T c(S T C)}=\sqrt{\left(u_{B}^{P T 1000}\right)^{2}+\left(u_{B}^{\Delta T 3}\right)^{2}+\left(u_{B}^{B T C}\right)^{2}+\left(u_{B}^{D a t, T c}\right)^{2}}=$

$\sqrt{(0.24)^{2}+(0.866)^{2}+(0.577)^{2}+(0.035)^{2}}=1.07^{\circ} \mathrm{o} C(4.3 \%)$

$u_{B}^{T c\left(50^{\circ} \mathrm{C}\right)}=\sqrt{(0.32)^{2}+(2.021)^{2}+(0.577)^{2}+(0.035)^{2}}=2.13^{\circ} \mathrm{C}(4.3 \%)$

Table 6 shows the combined Type B uncertainty on the directly measured electrical parameters $\left(I_{\mathrm{sc}}, V_{\mathrm{OC}}\right.$ and $\left.P_{\mathrm{MPP}}\right)$ in $\%$, as well as the uncertainty on $\alpha, b$ and $\gamma$ in $\% /{ }^{\circ} \mathrm{C}$. The subscript " $\mathrm{m}$ " indicates directly measured values. Uncertainties on $I_{\text {MPP }}$ and $V_{\text {MPP }}$, which are the inputs for $P_{\text {MPP }}$ uncertainty calculation, are considered to be the same as those corresponding to $I_{\mathrm{SC}}$ and $V_{\mathrm{OC}}$, respectively. As a matter of example, the uncertainty on $I_{\mathrm{sc}, \mathrm{m}}$ and $P_{\mathrm{MPP}, \mathrm{m}}$ are given by:

$u_{B}^{I_{S C, m}}=\sqrt{\left(u_{B}^{D A S}\right)^{2}+\left(u_{B}^{R e S}\right)^{2}}=\sqrt{(0.116)^{2}+(0.289)^{2}}=0.311 \%$

$u_{B}^{P_{M P P, m}}=\sqrt{\left(u_{B}^{I_{S C, m}}\right)^{2}+\left(u_{B}^{V_{O C, m}}\right)^{2}}=\sqrt{(0.311)^{2}+(0.116)^{2}}=0.332 \%$

\begin{tabular}{|c|c|c|c|c|c|c|}
\hline & $\begin{array}{l}I_{\mathrm{sc}, \mathrm{m}} \\
(\%)\end{array}$ & $\begin{array}{c}V_{\mathrm{OC}, \mathrm{m}} \\
(\%)\end{array}$ & $\begin{array}{c}P_{\mathrm{MPP}, \mathrm{m}} \\
(\%)\end{array}$ & $\begin{array}{c}\alpha_{\mathrm{Isc}} \\
\left(\% /{ }^{\circ} \mathrm{C}\right)\end{array}$ & $\begin{array}{l}B_{V_{o c}} \\
\left(\% /{ }^{\circ} \mathrm{C}\right)\end{array}$ & $\begin{array}{l}\gamma_{\mathrm{Pmpp}} \\
\left(\% /{ }^{\circ} \mathrm{C}\right)\end{array}$ \\
\hline Temperature & & & & 0.0045 & 0.026 & 0.036 \\
\hline D.A.S. & 0.116 & 0.116 & & & & \\
\hline Calib. Resistor & 0.289 & & & & & \\
\hline$I_{\text {measured }}$ & & & 0.311 & 0.0124 & & \\
\hline$V_{\text {measured }}$ & & & 0.116 & & 0.0045 & \\
\hline$P_{\text {measured }}$ & & & & & & 0.013 \\
\hline $\begin{array}{c}\text { Combined } \\
\boldsymbol{u}_{B}(\%)\end{array}$ & 0.311 & 0.116 & 0.332 & $\begin{array}{c}0.013 \\
(21.66 \%)\end{array}$ & $\begin{array}{c}0.026 \\
(8.13 \%)\end{array}$ & $\begin{array}{c}0.038 \\
(8.84 \%)\end{array}$ \\
\hline
\end{tabular}

Table 6. Standard Type B uncertainties on the measured current, voltage and power, and on the temperature coefficients $(\mathrm{k}=1)$.

Uncertainties on the temperature coefficients are estimated using the law of propagation of uncertainty: the combined standard uncertainty is the square root of the sum of the sensitivity coefficients (partial derivate of the equation with respect to the input parameter to be analyzed) squared, multiplied by its squared uncertainty.

$$
u_{c}(y)=\sqrt{\sum_{i=1}^{N}\left(\frac{\partial f}{\partial x_{i}}\right)^{2} u^{2}\left(x_{i}\right)}
$$


For example, in accordance with equation 1, the uncertainty sources for $\alpha$ are $I_{\mathrm{sc}, \mathrm{m}}$ and $T_{\mathrm{c}}$. The corresponding calculations are:

$\frac{\partial \alpha}{\partial I_{S C}}=\frac{1}{I_{S C}^{*}} \cdot \frac{1}{T_{C}-T_{C}^{*}} \approx \frac{1}{25}=0.04 \frac{1}{{ }^{\circ} \mathrm{C}}$

$\frac{\partial \alpha}{\partial T_{C}}=\frac{1}{I_{S C}^{*}} \cdot \frac{I_{S C}-I_{S C}^{*}}{\left(T_{C}-T_{C}^{*}\right)^{2}}=\frac{1}{8.61} \cdot \frac{0.115}{(25)^{2}} \cdot 100=2.14 \cdot 10^{-3} \frac{\%}{{ }^{\circ} C^{2}}$

$u_{B}^{\alpha}=\sqrt{\left(\frac{\partial \alpha}{\partial I_{S C}} \cdot u_{B}^{I_{S C, m}}\right)^{2}+\left(\frac{\partial \alpha}{\partial T_{C}} \cdot u_{B}^{T_{C}\left(50^{\circ} \mathrm{C}\right)}\right)^{2}}=$

$=\sqrt{(0.04 \cdot 0.311)^{2}+\left(2.14 \cdot 10^{-3} \cdot 2.13\right)^{2}}=0.013 \frac{\%}{{ }^{\circ} \mathrm{C}}(21.7 \%)$

Table 7 shows the uncertainty on the STC characteristics. Again, the propagation law is applied to consider the required corrections. For example, $I_{S C}^{*}$ is given by:

$$
I_{S C}^{*}=I_{S C} \cdot \frac{G^{*}}{G} \cdot \frac{1}{1+\alpha\left(T_{C}-T_{C}^{*}\right)}
$$

So $G, T_{C}, I_{\mathrm{SC}, \mathrm{m}}$ and $\alpha$ are the uncertainty sources. The corresponding calculations are:

$\frac{\partial I_{S C}^{*}}{\partial G}=\frac{I_{S C}}{1+\alpha\left(T_{C}-T_{C}^{*}\right)} \cdot \frac{-1}{G} \approx \frac{1}{1+\frac{0.06}{100}(1.07)}=0.999$

$\frac{\partial I_{S C}^{*}}{\partial T_{C}}=I_{S C} \frac{-\alpha}{\left[1+\alpha\left(T_{C}-T_{C}^{*}\right)\right]^{2}} \approx \frac{-0.06}{\left[1+\frac{0.06}{100}(1.07)\right]^{2}}=0.064 \%$

$\frac{\partial I_{S C}^{*}}{\partial I_{S C}}=\frac{1}{1+\alpha\left(T_{C}-T_{C}^{*}\right)}=\frac{1}{1+\frac{0.06}{100}(1.07)}=0.999$

$\frac{\partial I_{S C}^{*}}{\partial \alpha}=I_{S C} \frac{-\left(T_{C}-T_{C}^{*}\right)}{\left[1+\alpha\left(T_{C}-T_{C}^{*}\right)\right]^{2}} \approx \frac{-(1.07)}{\left[1+\frac{0.06}{100}(1.07)\right]^{2}}=1.069^{\circ} \mathrm{C}$

$u_{B}^{I_{S C}^{*}}=\sqrt{(0.999 \cdot 0.67)^{2}+(0.064 \cdot 1.07)^{2}+(0.999 \cdot 0.311)^{2}+(1.069 \cdot 0.013)^{2}}=0.742 \%(26)$

\begin{tabular}{|l|ccccc|}
\cline { 2 - 6 } \multicolumn{1}{c|}{} & $\begin{array}{c}I_{S C}^{*} \\
(\%)\end{array}$ & $\begin{array}{c}V_{O C}^{*} \\
(\%)\end{array}$ & $\begin{array}{c}P_{M P P}^{*} \\
(\%)\end{array}$ & $\begin{array}{c}F F^{*} \\
(\%)\end{array}$ & $\begin{array}{c}\eta^{*} \\
(\%)\end{array}$ \\
\hline Irradiance & 0.67 & & 0.67 & & 0.67 \\
Temperature & 0.064 & 0.345 & 0.464 & 0.183 & 0.464 \\
$I_{\text {measured }}$ & 0.311 & & & & \\
$\mathrm{~V}_{\text {measured }}$ & & 0.116 & & & \\
$\mathrm{P}_{\text {measured }}$ & & & 0.334 & & 0.334 \\
$\mathrm{FF}_{\text {measured }}$ & & & & 0.334 & \\
$\alpha_{\text {Isc }}$ & 0.014 & & & &
\end{tabular}




\begin{tabular}{|c|c|c|c|c|c|}
\hline$\beta_{\text {Voc }}$ & & 0.028 & & & \\
\hline$\gamma_{\text {Pmpp }}$ & & & 0.041 & & 0.041 \\
\hline$\delta_{\mathrm{FF}}$ & & & \multicolumn{3}{|c|}{0.001} \\
\hline $\begin{array}{c}\text { Combined } \\
u_{B}(\%)\end{array}$ & 0.742 & 0.365 & 0.882 & 0.381 & 0.882 \\
\hline
\end{tabular}

Table 7. Standard Type B uncertainties on the extrapolated current, voltage, power, $F F$ and efficiency.

\subsection{Combined and expanded uncertainties}

Again, the uncertainty components are considered as mutually independent. Hence, the combined uncertainty for a particular result is given by:

$$
u_{C, R E S}=\sqrt[2]{u_{A, R E S}^{2}+\sum_{i}\left(u_{B, R E S}^{i}\right)^{2}}
$$

where " $\mathrm{i}$ " stands for all the Type B components. Table 8 shows the combined standard uncertainty on the STC parameters and on the temperature coefficients.

\begin{tabular}{|c|c|c|c|c|c|c|c|}
\hline $\begin{array}{c}\boldsymbol{u}_{C, P_{M P P}^{*}} \\
(\%)\end{array}$ & $\begin{array}{c}\boldsymbol{u}_{C, I_{S C}^{*}} \\
(\%)\end{array}$ & $\begin{array}{c}\boldsymbol{u}_{C, V_{O C}^{*}} \\
(\%)\end{array}$ & $\begin{array}{c}\boldsymbol{u}_{\boldsymbol{C}, \boldsymbol{F} \boldsymbol{F}^{*}} \\
(\%)\end{array}$ & $\begin{array}{c}\mathbf{u}_{\mathbf{C}, \alpha} \\
\left(\% /{ }^{\circ} \mathrm{C}\right)\end{array}$ & $\begin{array}{c}\mathbf{u}_{\mathrm{C}, \boldsymbol{\beta}} \\
\left(\% /{ }^{\circ} \mathrm{C}\right)\end{array}$ & $\begin{array}{c}\mathbf{u}_{\mathrm{C}, \mathrm{y}} \\
\left(\% /{ }^{\circ} \mathrm{C}\right)\end{array}$ & $\begin{array}{r}u_{C, \eta^{\prime}} \\
(\%)\end{array}$ \\
\hline 0.935 & 0.858 & 0.399 & 0.45 & $\begin{array}{c}0.015 \\
(25.43 \%)\end{array}$ & $\begin{array}{c}0.028 \\
(8.71 \%)\end{array}$ & $\begin{array}{c}0.042 \\
(9.88 \%)\end{array}$ & 0.935 \\
\hline
\end{tabular}

Table 8. Combined standard uncertainty on the STC parameters and on the temperature coefficients.

\subsection{Intercomparison}

We have compared the results of our outdoor measurements for three different modules with the results from a high quality pulsed solar simulator available at the Centro de Investigaciones Energéticas, Medioambientales y Tecnológicas - CIEMAT (Pasan 3b with class AAA in accordance with IEC 60904-9 with a flash duration of $10 \mathrm{~ms}$ ), respectively. Table 9 shows the results. The maximum power is within $\pm 0.7 \%$, which is of the order of the differences observed at worldwide intercomparison between reference laboratories ( $\pm 1.3 \%$ for crystalline silicon modules (Dirnberger et al., 2014)).

\begin{tabular}{|c|c|c|c|c|c|c|}
\hline & $\begin{array}{c}P_{M P P}^{*} \\
\text { (W) }\end{array}$ & $\begin{array}{c}I_{M P P}^{*} \\
\text { (A) }\end{array}$ & $\begin{array}{c}V_{M P P}^{*} \\
\text { (V) }\end{array}$ & $\begin{array}{l}I_{S C}^{*} \\
(\mathrm{~A})\end{array}$ & $\begin{array}{c}V_{O C}^{*} \\
\text { (V) }\end{array}$ & $\boldsymbol{F F}^{*}$ \\
\hline \multicolumn{7}{|c|}{ M1: Atersa A245P, 60 polycrystalline-Si cells, $P_{N O M}^{*}=245 W_{P}$} \\
\hline Flash CIEMAT & 239.7 & 7.96 & 30.12 & 8.56 & 37.46 & 0.748 \\
\hline Outdoor IES & 241.0 & 8.08 & 29.83 & 8.60 & 37.60 & 0.750 \\
\hline Difference (\%) & 0.54 & 1.51 & -0.96 & 0.47 & 0.37 & 0.27 \\
\hline \multicolumn{7}{|c|}{ M2: Solon P215, 60 polycrystalline-Si cells, $P_{N O M}^{*}=215 W_{P}$} \\
\hline Flash CIEMAT & 209.2 & 7.40 & 28.27 & 7.99 & 36.16 & 0.724 \\
\hline Outdoor IES & 209.0 & 7.44 & 28.09 & 8.03 & 36.29 & 0.717 \\
\hline
\end{tabular}




\begin{tabular}{|lrrrrrrr|} 
Difference (\%) & $\mathbf{0 . 1 1}$ & $\mathbf{0 . 5 0}$ & $\mathbf{- 0 . 6 3}$ & $\mathbf{0 . 4 6}$ & $\mathbf{0 . 3 5}$ & $\mathbf{- 0 . 9 7}$ \\
& M3: Yingli YL230, 60 monocrystalline-Si & cells, $P_{N O M}^{*}$ & $=230 W_{P}$ & & \\
Flash CIEMAT & 235.5 & 7.98 & 29.49 & 8.44 & 36.72 & 0.760 \\
Outdoor IES & 236.6 & 8.04 & 29.43 & 8.51 & 36.80 & 0.756 \\
Difference (\%) & $\mathbf{0 . 4 5}$ & $\mathbf{0 . 7 2}$ & $-\mathbf{0 . 2 0}$ & $\mathbf{0 . 8 0}$ & $\mathbf{0 . 2 3}$ & $-\mathbf{0 . 5 6}$ \\
\hline
\end{tabular}

Table 9. Difference in the results of the measurements with the solar simulators from CIEMAT and measurements taken at real sun with the "Solar Box".

It is worth mentioning that we also had a medium quality pulsed solar simulator (Berger PSS 8 with class A, flash duration of $10 \mathrm{~ms}$ ). The irradiance level is adjusted with the same reference cell we used for outdoor measurements. Table 10 compares the measurements from both solar simulators. Interestingly, the differences are larger than those corresponding to the outdoor measurements.

\begin{tabular}{|c|c|c|c|c|c|c|}
\hline & $\begin{array}{c}P_{M P P}^{*} \\
\text { (W) }\end{array}$ & $\begin{array}{c}I_{M P P}^{*} \\
\text { (A) }\end{array}$ & $\begin{array}{c}V_{M P P}^{*} \\
\text { (V) }\end{array}$ & $\begin{array}{l}I_{S C}^{*} \\
(\mathrm{~A})\end{array}$ & $\begin{array}{l}V_{O C}^{*} \\
\text { (V) }\end{array}$ & $\boldsymbol{F F}^{*}$ \\
\hline \multicolumn{7}{|c|}{ M1: Atersa A245P, 60 polycrystalline-Si cells, $P_{N O M}^{*}=245 W_{P}$} \\
\hline Flash CIEMAT & 239.7 & 7.96 & 30.12 & 8.56 & 37.46 & 0.748 \\
\hline Flash IES & 244.3 & 8.03 & 30.43 & 8.59 & 37.45 & 0.760 \\
\hline Difference (\%) & 1.92 & 0.88 & 1.03 & 0.35 & -0.03 & 1.58 \\
\hline \multicolumn{7}{|c|}{ M2: Solon P215, 60 polycrystalline-Si cells, $P_{N O M}^{*}=215 W_{P}$} \\
\hline Flash CIEMAT & 209.2 & 7.40 & 28.27 & 7.99 & 36.16 & 0.724 \\
\hline Flash IES & 212.5 & 7.46 & 28.48 & 7.96 & 36.11 & 0.739 \\
\hline Difference (\%) & 1.57 & 0.81 & 0.74 & -0.38 & -0.14 & 2.06 \\
\hline \multicolumn{7}{|c|}{ M3: Yingli YL230, 60 monocrystalline-Si cells, $P_{N O M}^{*}=230 W_{P}$} \\
\hline Flash CIEMAT & 235.5 & 7.98 & 29.49 & 8.44 & 36.72 & 0.760 \\
\hline Flash IES & 240.8 & 7.98 & 30.17 & 8.52 & 36.70 & 0.770 \\
\hline Difference (\%) & 2.23 & 0.00 & 2.31 & 0.95 & -0.05 & 1.30 \\
\hline
\end{tabular}

Table 10. Difference in the results of the measurements with the solar simulators from CIEMAT and IES-UPM.

Finally, it should be mentioned that the "Solar Box" materials cost is only about $1500 €$ (wood: $80 €$; insulation: $40 €$; fans: $50 €$; support structure: $850 €$; reference cell: $500 €)$. This box must be used in combination with additional components (a laptop computer, a capacitive load, an airconditioning system and temperature sensors), that cost must be also taken into account. The total cost is, approximately, $4500 €$.

\section{Uncertainty on PV reference module measurements}

As a representative case, we have prepared 20 PV modules of the same model (Yingli YL250-29b $250 \mathrm{~W}_{\mathrm{p}}$ ) to be used as $G_{\mathrm{ef}}$ and $T_{\mathrm{C}}$ sensors in large PV plants. All of them were previously submitted to an exposure to the Sun of about $60 \mathrm{kWh} / \mathrm{m}^{2}$ and revised using electroluminescence, in order to assure that they are well stabilized and fully free of internal defects. Half of them are going to be used as $G_{\text {ef }}$ sensors. For that, they were shunted by means of calibrated resistors (Class 0.5 , high thermal stability). Corresponding irradiance signals are the drop in voltage at these resistors. The other half is going to be used as $T_{\mathrm{C}}$ sensors, which corresponding signals are the open circuit voltages. All of them were individually calibrated as described in the previous section, but the 
calibration of $I_{\mathrm{SC}}$ was substituted by the calibration of the direct irradiance signal, which leads to the Type B uncertainty corresponding to the calibrated resistor being avoided.

Next, we installed the $20 \mathrm{PV}$ modules on the same surface $\left(30^{\circ}\right.$ tilted, South oriented) and we compared their $G_{\text {ef }}$ and $T_{\mathrm{C}}$ measurements over several days (May $19^{\text {th }}$ and $20^{\text {th }}, 2016$ for $G_{\text {ef }}$ and June $2^{\text {nd }}$ and $5^{\text {th }}, 2016$ for $T_{\mathrm{C}}$ ). The corresponding differences have been the basis for estimating the uncertainty.

\subsection{Uncertainty on irradiance}

As a representative example, Fig. 7 shows the average of the $10 G_{\text {ef }}$ individual measurements and the corresponding difference between each individual measurement and this average. Differences are within $\pm 1 \%$, which is consistent with the uncertainties on the $I_{S C}^{*}$ characterization described above ( $1 \%$ is close to one standard deviation). As all of the PV modules receive the same irradiance, the uncertainty on the average value is less than for the measurement of a single PV module. In particular, Type A uncertainty is divided by $\sqrt{N}, N$ being the number of PV modules. This allows the calibration to be refined in such a way that all of the modules give measurements as close as possible to the average value. Fig. 8 shows the evolution of the difference in the irradiance measured by two of these PV modules - after refining the calibration - versus the angle of incidence of the direct irradiance component, $\vartheta_{s}$. The key point is to realize that the difference increases sharply for $\vartheta_{S}>50^{\circ}$, which can be explained by slight differences in angle of incidence, due to the frame not being perfectly flat all over. The resulting standard uncertainty is $0.93 \%$ for $\vartheta_{\mathrm{S}}$ $\leq 50^{\circ}$ (Type A: $0.43 \%$, Type B: $0.82 \%$ ) and $1.36 \%$ for $\vartheta_{s}>50^{\circ}$ (Type A: $0.43 \%$, Type B: $1.35 \%$ ).

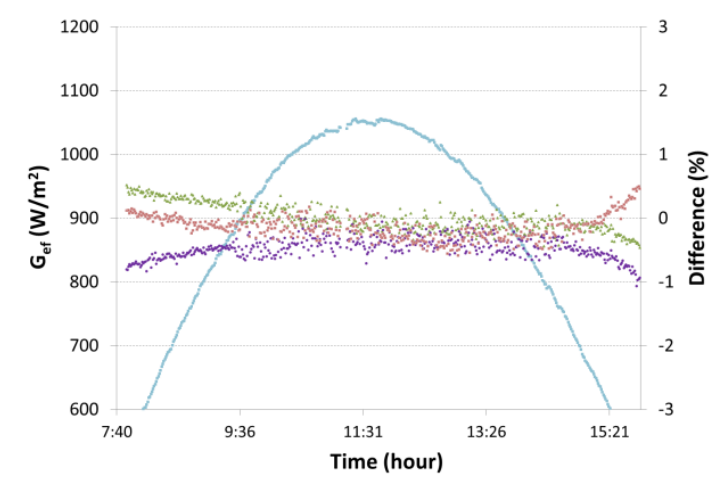

Fig. 7. Effective irradiance, $G_{\text {ef }}$, obtained by the average of the $10 \mathrm{PV}$ modules and differences between this average and each module for irradiances above $600 \mathrm{~W} / \mathrm{m}^{2}$ (for clarity of presentation, the differences are shown for only three modules). Measurements have been recorded on May 19 ${ }^{\text {th }}, 2016$. 


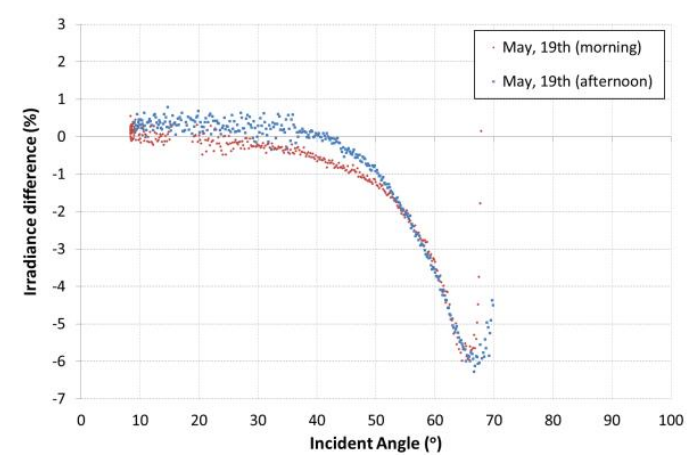

Fig. 8. Difference in the effective irradiance measured by two reference modules on a clear day (May $19^{\text {th }}$ ) versus the angle of incidence.

\subsection{Uncertainty on PV module temperature}

Fig. 9 shows the 10 values of $T_{C}$ measured with clear sky (June $2^{\text {nd }}, 2016$ ) with a cell temperature close to $65^{\circ} \mathrm{C}$ at noon. The maximum difference between PV modules during the two days of $T_{\mathrm{C}}$ calibration (June $2^{\text {nd }}$ and $5^{\text {th }}, 2016$ ) is $\pm 3.3^{\circ} \mathrm{C}$. These differences are within the expected range, because the thermal dissipation process influences the module and varies from one PV module to another, even if they are from the same manufacturer, model and type of cell. For this reason, possible calibration refinements based on compensating this difference have been disregarded. The resulting combined standard uncertainty is $0.381 \%$ (Type A: $0.16 \%$, Type B: $0.381 \%$ ), for $k=1$.

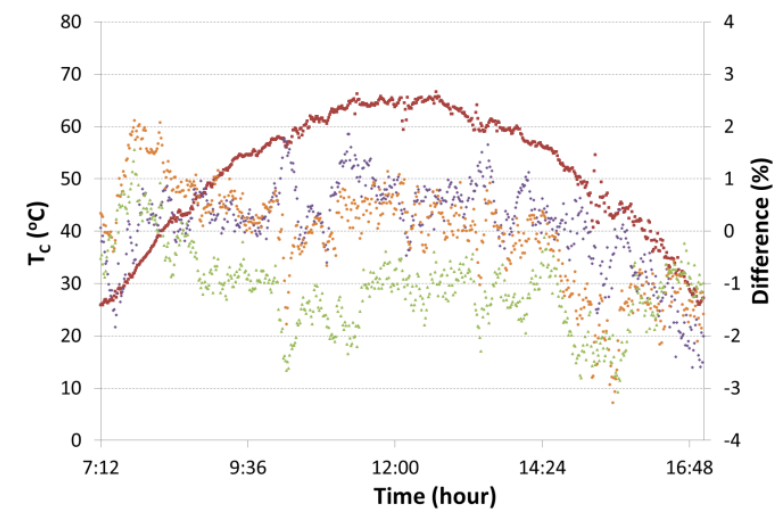

Fig. 9. Module temperature obtained by the average of the $10 \mathrm{PV}$ modules and differences between this average and each module (for clarity of presentation, the differences are shown for only three modules). Measurements have been recorded on June $2^{\text {nd }}, 2016$.

\section{Conclusions}

The IES-UPM experience with the outdoor characterization of c-Si PV modules and calibration of reference modules has been presented. Clear sky conditions are common in Madrid. Taking 
advantage of this pleasant circumstance, a home-made "Solar Box", which is a simple, thermallyinsulated wooden box with polystyrene and equipped with a standard air-conditioning system, allows us to measure the characteristics of the PV modules at Standard Test Conditions and also to measure the temperature coefficients. I-V curves are also obtained by means of a home-made capacitive load, whose capacitor is adjusted to ensure charging times of at least $20 \mathrm{~ms}$, in order to avoid voltage-sweep related $F F$ disturbances.

We have paid particular attention to the calibration of the reference solar cell used for measuring irradiance. This device makes our measurements traceable to the S.I. and represents the major contribution to uncertainty. By crossing different independent calibrations, including our participation at the $5^{\text {th }}$ International Spectro - and Broadband Radiometer Intercomparison, we established the calibration value with an expanded uncertainty of $1.34 \%(k=2)$. Together with standard electrical precautions, such as four-point Kelvin probe I-V measurements, this leads to the following expanded uncertainties $(\mathrm{k}=2)$ on the STC characterization parameters: $1.87 \%$ in $P_{M P P}^{*}, 1.72 \%$ in $I_{S C}^{*}, 0.80 \%$ in $V_{O C}^{*}$ and $0.90 \%$ in $F F^{*}$. On the other hand, we also use the "Solar Box" for calibrating reference PV modules as irradiance and module temperature sensors. We relate the corresponding uncertainty to the angle of incidence of the direct irradiance. The resulting expanded uncertainties ( $k=2$ ) on $G_{\text {ef }}$ for angles below (above) $50^{\circ}$ are $0.93 \%(1.36 \%$ ) and $0.38 \%$ on $T_{\mathrm{c}}$. These values are in the order of those corresponding to high accuracy solar simulators, and allow their involvement in the technical quality assurance of large PV plants.

We think this experience can help to open the door to high-quality PV measurements without the need for rather expensive solar simulators. This is of interest for local measurements in the growing number of countries currently incorporating PV plants into their electric grids, but still lacking PV specialized laboratories, and enjoying frequent clear sky conditions. In fact, our work has been developed simply within the framework of the quality assurance processes for these PV plants.

\section{ACKNOWLEDGEMENTS}

We greatly appreciate the attention received from the organization of the $5^{\text {th }}$ International Spectro and Broadband Radiometer Intercomparison and we would like to thank the CIEMAT for its constant help with the reference cell calibration and PV-module characterization. We also want to thank Carlos Henrique Rossa and Jose Ferreira for their help with efficiency versus irradiance measurements. This work has been developed within the FP7 European Program (Energy) in the PhotoVoltaic Cost reduction, Reliability, Operational performance, Prediction and Simulation project (PVCROPS), Project reference 308468 (www.pvcrops.eu). Anonymous reviewers provided valuable comments.

\section{APPENDIX}




\section{A. The calibration of the reference solar cell}

The traceability of our measurements to the S.I. is established through a c-Si reference solar cell (ISET sensor) we acquired in 2013 from IKS Photovoltaik. It provides an irradiance signal (from an internal resistor, short-circuiting the cell) and a temperature signal (from an internal PT1000). The cell was delivered with a calibration certificate from the Fraunhofer-ISE (2626-13). The calibration value is $92.025 \mathrm{mV} /\left(\mathrm{kW} / \mathrm{m}^{2}\right) \pm 4 \%(\mathrm{k}=2)$ with the cell at $25^{\circ} \mathrm{C}$. Furthermore, the instruction manual of the ISET sensor says that the temperature coefficient for irradiance is $0.065 \pm 0.015 \% /{ }^{\circ} \mathrm{C}$.

As this cell plays a key role in our measurement uncertainties, we have paid particular attention to its calibration, submitting it to the three additional calibration procedures as summarized in Table A.1. In all the cases the initial calibration value is given by the slope of the direct irradiance signal of the solar cell plotted against the irradiance seen by a coplanar reference device traceable to the S.I. Now, appropriate angular, spectral and temperature corrections must be applied to take into account the difference among the calibration procedures:

\begin{tabular}{|c|c|c|c|c|c|c|}
\hline \multicolumn{7}{|c|}{ Independent calibrations } \\
\hline \multirow[b]{2}{*}{ Date } & \multirow[b]{2}{*}{$\begin{array}{l}\text { Calibration } \\
\text { body }\end{array}$} & \multicolumn{2}{|c|}{ Initial calibration } & \multirow[b]{2}{*}{ Procedure } & \multicolumn{2}{|c|}{ Corrected calibration } \\
\hline & & $\begin{array}{c}\text { Value } \\
\left(\mathrm{mV} /\left(\mathrm{kW} / \mathrm{m}^{2}\right)\right)\end{array}$ & $\begin{array}{c}\text { Standard } \\
\text { deviation } \\
(\%)\end{array}$ & & $\begin{array}{c}\text { Value } \\
\left(\mathrm{mV} /\left(\mathrm{kW} / \mathrm{m}^{2}\right)\right)\end{array}$ & $\begin{array}{c}\text { Standard } \\
\text { deviation } \\
(\%)\end{array}$ \\
\hline $\begin{array}{l}\text { March } \\
2013\end{array}$ & FISE & 92.025 & 2 & $\begin{array}{c}\text { At a solar } \\
\text { simulator against } \\
\text { a reference cell }\end{array}$ & 92.025 & 2 \\
\hline $\begin{array}{l}\text { July } \\
2014\end{array}$ & CIEMAT & 90.4 & 1 & $\begin{array}{c}\text { At natural } \\
\text { sunlight against } \\
\text { the global } \\
\text { irradiance given } \\
\text { by a } \\
\text { pyranometer }\end{array}$ & 90.354 & 1.459 \\
\hline $\begin{array}{l}\text { May } \\
2015\end{array}$ & $\begin{array}{l}5^{\text {th }} \text { International } \\
\text { Spectro - and } \\
\text { Broadband } \\
\text { Radiometer } \\
\text { Intercomparison }\end{array}$ & 90.84 & 0.87 & $\begin{array}{l}\text { At natural } \\
\text { sunlight against } \\
\text { the global } \\
\text { irradiance given } \\
\text { by a cavity } \\
\text { pyrheliometer } \\
\text { and a shaded } \\
\text { pyranometer }\end{array}$ & 90.796 & 0.988 \\
\hline $\begin{array}{c}\text { February } \\
2017\end{array}$ & IES-UPM & 91.384 & 1.05 & $\begin{array}{c}\text { At natural } \\
\text { sunlight against } \\
\text { a reference cell } \\
\text { calibrated by } \\
\text { NREL }\end{array}$ & 91.089 & 1.445 \\
\hline
\end{tabular}


Table A.1 Calibration procedures carried out by different laboratories. Likewise, the initial calibration values are also shown with their respective uncertainties $(\mathrm{k}=1)$ and corrected for temperature, angle and AM.

The FISE calibration was carried out on a solar simulator against a c-Si primary reference cell which, in turn, was calibrated at the PTB (Dirnberger and Kräling, 2013) by means of the so-called DSR calibration method (Metzdorf et al., 2000). In both calibration steps all the light is inside the angle of acceptance of the concerned cell $\left(\approx 60^{\circ}\right)$. Furthermore, the cell temperature is kept at $25^{\circ} \mathrm{C}$. No corrections are needed.

At the $5^{\text {th }}$ International Spectro - and Broadband Radiometer Intercomparison, the calibration was carried out on days with clear sky conditions. The solar cell, three cavity radiometers (for direct irradiance traceable to the WRR (Fröhlich, 1991), having a combined uncertainty of $0.103 \%$ (Galleano and Zaaiman, 2016)) and a shaded pyranometer (for diffuse irradiance, calibrated by the sun and shade method against the cavities and having an uncertainty of $0.78 \%$ ) tracked the Sun. This is somewhat close to the so-called global sunlight method for primary photovoltaic reference cells (Müllejans et al., 2005a). The measuring campaign was carried out in Madrid, from May $18^{\text {th }}$ to $22^{\text {th }} 2015$. The calibration period was within \pm 3 hours around midday and that AM-corrected pressure ranged from 1.0 to 1.6. The result (after the appropriate filtering: $G>800 \mathrm{~W} / \mathrm{m}^{2}$, difference between cavity radiometers $<1 \mathrm{~W} / \mathrm{m}^{2}$ ) is a set of more than 700 valid measurements, each made up of four values: the irradiance signal of our cell, the direct irradiance given by the cavities, the diffuse irradiance given by the shaded pyranometer and the ambient temperature. Unfortunately, the temperature signal of our cell was not stored. The standard deviation of the initial calibration is $0.87 \%$ (Type A: $0.86 \%$ and Type B: $0.10 \%$ ). However, the angle of acceptance of the pyranometer $\left(\approx 90^{\circ}\right)$ is larger than that corresponding to the cell. An angular correction is divided into two steps. First, considering that the diffuse irradiance has two components: one isotropic, $D^{\prime}$, and another circumsolar, $D^{C}$. According with Hay (Hay and McKay, 1985), the isotropic component can be estimated as:

$$
D^{I}=D\left(1-\frac{B}{B_{0} \varepsilon_{0}}\right)
$$

where $B_{0}$ and $\varepsilon_{0}$ are, respectively, the solar constant $\left(1367 \mathrm{~W} / \mathrm{m}^{2}\right)$ and the eccentricity factor of the day. The ratio $D^{\prime} / D$ on the results of the measuring campaign ranges from between 0.24 and 0.40 . Second, considering that the ratio between the isotropic irradiance seen by two devices with acceptance angles $\alpha_{1}$ and $\alpha_{2}$ is:

$$
\frac{D_{\alpha_{1}}^{I}}{D_{\alpha_{2}}^{I}}=\left(\frac{\sin \alpha_{1}}{\sin \alpha_{2}}\right)^{2}
$$


In our case, $\frac{D_{\alpha_{1}}^{I}}{D_{\alpha_{2}}^{I}}=0.75$. Furthermore, a spectral correction for the direct irradiance can be derived using the empirical polynomial regression between AM and the relative short-circuit response, considered at the so-called SANDIA PV performance model (King et al., 2004; Osterwald et al., 2014).

$$
\begin{gathered}
I_{S C}(A M)=I_{S C}(1.5) \times f(A M) \\
f(A M)=a_{0}+a_{1} A M+a_{2} A M^{2}+a_{3} A M^{3}+a_{4} A M^{4}
\end{gathered}
$$

where $a_{0}$ to $a_{4}$ are empirical coefficients for each particular PV device. We have used typical values from the Sandia module database (Sandia, 2013) for c-Si modules: $a_{0}=0.9315, a_{1}=0.05975, a_{2}=-$ $0.01067, a_{3}=0.0008$ and $a_{4}=-0.0000224$. It is worth remembering that the incident spectrum not only depends on $A M$ but also on aerosols and water vapor content at the Atmosphere. Hence, because these parameters are not taken into account, some uncertainty associated to spectral effects must remain even after applying this correction.

Finally, the irradiance signal can be corrected to $25^{\circ} \mathrm{C}$, taking into account the solar cell temperature (estimated from the ambient temperature and the global irradiance) and the corresponding coefficient provided by the cell manufacturer. That leads to a final corrected calibration value of $90.796 \mathrm{mV} /\left(\mathrm{kW} / \mathrm{m}^{2}\right)$. The corresponding uncertainty is $0.988 \%$ for $\mathrm{k}=1$ (Type A: $0.67 \%$; Type B: $0.730 \%$, where $0.107 \%$ comes from the reference sensors, $0.174 \%$ from the angle correction, $0.674 \%$ from the temperature correction and $0.180 \%$ from the AM correction). Interestingly, the final dispersion of the corrected data (Type A: $0.67 \%$ ) is less than the dispersion of the data without making any correction (Type A: $0.86 \%$ ), which is a symptom of the soundness of the corrections.

The CIEMAT calibration has carried out on a day with clear sky conditions. The solar cell concerned and a secondary pyranometer were exposed to the Sun at $40.4^{\circ}$ latitude on a tilted and southoriented surface. The calibration was carried out for an irradiance of more than $600 \mathrm{~W} / \mathrm{m}^{2}$. The uncertainty reported by the CIEMAT is $1 \%(\mathrm{k}=1)$. Again, corrections can be made for the angle of acceptance (we have assumed a diffuse/global ratio equal to $10 \%$ ), for the spectrum and the solar cell temperature. The final corrected calibration value is $90.354 \mathrm{mV} /\left(\mathrm{kW} / \mathrm{m}^{2}\right)$ with an uncertainty of $1.459 \%$ (Type A: $0.783 \%$; Type B: $1.23 \%$ where $1 \%$ comes from the CIEMAT calibration, $0.174 \%$ from the angle correction, $0.674 \%$ from the temperature correction and $0.180 \%$ from the $A M$ correction).

The internal calibration was also carried out on a day with clear sky conditions. The cell concerned and a secondary reference cell calibrated by the NREL with an uncertainty of $0.7 \%(\mathrm{k}=1)$ are exposed to the Sun, and the calibration is made for $G \geq 800 \mathrm{~W} / \mathrm{m}^{2}$. The NREL calibration is made at a solar simulator against a primary reference c-Si. Only temperature corrections are required.

Interestingly, the primary devices at the origin of the corresponding traceability chains are different, so that we can consider these calibrations as mutually independent and derive the 
weighted average and their expanded uncertainty, following (Cox, 2007; Müllejans et al., 2005a) as:

$$
\bar{x}=\frac{\sum_{i=1}^{n} w_{i} x_{i}}{\sum_{i=1}^{n} w_{i}}=\frac{\sum_{i=1}^{n} \frac{x_{i}}{\sigma_{i}^{2}}}{\sum_{i=1}^{n} \frac{1}{\sigma_{i}^{2}}}
$$

with $w_{i}=\frac{1}{\sigma_{i}^{2}}$, and $\sigma_{i}=\frac{U C 95 \%(k=2)}{2}$, where $\bar{x}$ is the weighted mean, $w_{i}$ is the weight assigned to each calibration and $\sigma_{i}$ corresponds to the standard deviation of each calibration. The weighted means standard deviation can be calculated by:

$$
\sigma_{\bar{x}}=\frac{\sqrt{\sum_{i=1}^{n} w_{i}^{2} \sigma_{i}^{2}}}{\sum_{i=1}^{n} w_{i}}=\frac{1}{\sqrt{\sum_{i=1}^{n} \frac{1}{\sigma_{i}^{2}}}}
$$

Fig.A.1 shows the different calibration values:

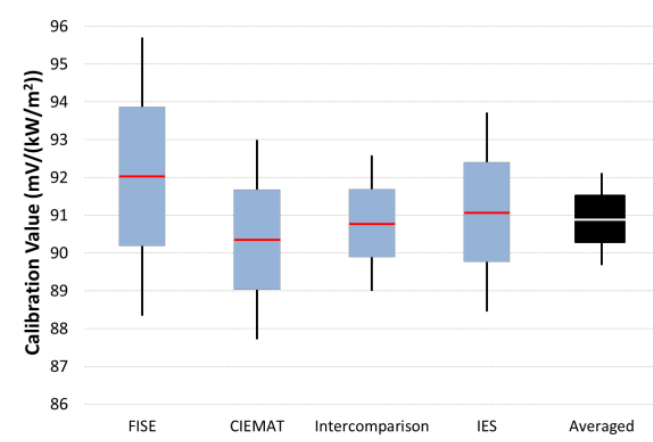

Fig.A.1. Calibration values of the reference cell from different laboratories once they have been corrected by thermal, angular and AM effects (see Table A.1). The red horizontal lines correspond to the calibration values, the rectangles limit $\pm \sigma$ intervals and the vertical lines limit $\pm 2 \sigma$ intervals. The last one, in black and with the horizontal line in white, corresponds to weighted average.

It could be said that, as the initial calibration value provided by the reference cell manufacturer is very close to the final value assigned after comparing different calibrations, this rather painstaking comparison exercise is superfluous. However, we must warn against this idea. In fact, we have acquired two reference cells from the same manufacturer and their corresponding $G_{\text {ef }}$ measurements, when exposed together to the sun and using their initial calibration values, differ consistently by about $3.4 \%$. This difference is consistent with the expanded uncertainty claimed by the manufacturer ( $4 \%$ for $\mathrm{k}=2$ ), but not with the uncertainty reached after the comparison performed here. It is also worth mentioning that the final uncertainty $(0.67 \%)$ is lower than the lowest reported for calibration at pulsed solar simulators (Plag et al., 2014). 


\section{REFERENCES}

AERONET [WWW Document], 2006. URL https://aeronet.gsfc.nasa.gov/

Atmaram, G.H., 2006. Uncertainty estimate of photovoltaic module power rating for outdoor testing, in: 4th World Conference on Photovoltaic Energy Conference. pp. 2124-2128.

Caamaño, E., Lorenzo, E., Zilles, R., 1999. Quality Control of Wide Collections of PV Modules: Lessons Learned from the. Prog. Photovoltaics Res. Appl. 7, 137-149.

Campanelli, M.B., Osterwald, C.R., 2016. Effective Irradiance Ratios to Improve I - V Curve Measurements and Diode Modeling Over a Range of Temperature and Spectral and Total Irradiance. IEEE J. Photovoltaics 6, 48-55. doi:10.1109/JPHOTOV.2015.2489866

Coello, J., Pérez, L., Domínguez, F., Navarrete, M., 2014. On-site quality control of photovoltaic modules with the PV MOBILE LAB. Energy Procedia 57, 89-98. doi:10.1016/j.egypro.2014.10.012

Cox, M.G., 2007. The evaluation of key comparison data: determining the largest consistent subset. Metrologia 44, 187-200. doi:10.1088/0026-1394/44/3/005

De la Parra, I., Muñoz, M., Lorenzo, E., García, M., Marcos, J., Martínez-Moreno, F., 2017. PV performance modelling: A review in the light of the quality assurance for large PV plants.

Dirnberger, D., Kräling, U., 2013. PTB: Physikalisch-Technische Bundesanstalt. FISE calibration. Uncertainty in PV Module Measurement-Part1: Calibration of Crystalline and Thin-Film Modules. IEEE J. Photovoltaics 3, 1016-1026.

Dirnberger, D., Kräling, U., Müllejans, H., Salis, E., Emery, K., Hishikawa, Y., 2014. Progress in photovoltaic module calibration: results of a worldwide intercomparison between four reference laboratories. IOP Publ. Meas. Sci. Technol. 25, 1-17. doi:10.1088/09570233/25/10/105005

Fröhlich, C., 1991. History of Solar Radiometry and the World Radiometric Reference. Metrologia 28, 111-115.

Galleano, R., Zaaiman, W., 2016. Validation and benchmarking of broadband- and spectralradiometers. doi:10.2790/579648

Gan, G., 2009. Effect of air gap on the performance of building-integrated photovoltaics. Energy 34, 913-921. doi:10.1016/j.energy.2009.04.003

Hay, J.E., McKay, D.C., 1985. Estimating Solar Irradiance on Inclined Surfaces: A Review and Assessment of Methodologies. Sol. Energy 3, 203-240. doi:http://dx.doi.org/10.1080/01425918508914395

Huang, B.J., Yang, P.E., Lin, Y.P., Lin, B.Y., Chen, H.J., Lai, R.C., Cheng, J.S., 2011. Solar cell junction temperature measurement of PV module. Sol. Energy 85, 388-392. doi:10.1016/j.solener.2010.11.006

IEC:60904-1, 2006. Photovoltaic devices - Part 1: Measurement of photovoltaic current-voltage characteristics. 
IEC:60904-4, 2011. Photovoltaic devices - Part 4: Reference solar devices. Procedures for establishing calibration traceability.

IEC:60904-9, 2007. Photovoltaic devices. Part 9: Solar simulator performance requirements.

IEC 60891, 2009. Photovoltaic devices - Procedures for temperature and irradiance corrections to measured I-V characteristics.

ISO/IEC-Guide98-3, 2008. Evaluation of measurement data - Part 3: Guide to the expression of uncertainty in measurement. Switzerland.

Keogh, W.M., Blakers, A.W., 2004. Accurate Measurement, Using Natural Sunlight, of Silicon Solar Cells. Prog. Photovoltaics Res. Appl. 12, 1-19. doi:10.1002/pip.517

King, D.L., Boyson, W.E., Kratochvill, J.A., 2004. Photovoltaic Array Performance Model. Albuquerque, NM.

King, D.L., Kratochvill, J.A., Boyson, W.E., 1998. Field Experience with a New Performance Characterization Procedure for Photovoltaic Arrays, in: 2nd World Conference and Exhibition on Photovoltaic Solar Energy Conversion. Vienna, pp. 1-8.

King, D.L., Kratochvill, J.A., Boyson, W.E., 1997. Temperature coefficients for PV modules and arrays: measurement methods, difficulties, and results, in: Conference Record of the 26th IEEE. IEEE, Anaheim, CA, pp. 1183-1186.

Martínez-Moreno, F., Lorenzo, E., 2015. PVCROPS Deliverable 2.3: Technical specification for grid connected PV systems ready to include in contractual frameworks. Madrid.

Martínez-Moreno, F., Tyutyundzhiev, N., 2015. PVCROPS Deliverable 9.4: Description of testing kits. Madrid.

Metzdorf, J., Winter, S., Wittchen, T., 2000. Radiometry in photovoltaics: calibration of reference solar cells and evaluation of reference values. IOP Publ. Meas. Sci. Technol. 37, 573-578.

Mobile PV Testcenter. Intertek [WWW Document], 2016. URL http://www.intertek.com/solar/mobile/

Mobile quality control. Sun Energy Europe [WWW Document], 2012. URL http://www.sunenergy.eu/en/services/mobile-quality-control.html

Müllejans, H., Zaaiman, W., Dunlop, E.D., 2015. Reduction of uncertainties for photovoltaic reference cells. IOP Publ. Meas. Sci. Technol. 52, 646-653. doi:10.1088/0026-1394/52/5/646

Müllejans, H., Zaaiman, W., Dunlop, E.D., Ossenbrink, H.A., 2005a. Calibration of photovoltaic reference cells by the global sunlight method. Metrologia 42, 360-367. doi:10.1088/0026$1394 / 42 / 5 / 004$

Müllejans, H., Zaaiman, W., Galleano, R., 2009. Analysis and mitigation of measurement uncertainties in the traceability chain for the calibration of photovoltaic devices. IOP Publ. Meas. Sci. Technol. 20. doi:10.1088/0957-0233/20/7/075101

Müllejans, H., Zaaiman, W., Merli, F., Dunlop, E.D., 2005b. Comparison of Traceable Calibration 
Methods for Primary Photovoltaic Reference Cells. Prog. Photovoltaics Res. Appl. 13, 661671. doi:10.1002/pip.625

Muñoz, J., Lorenzo, E., Carrillo, J.M., Moretón, R., 2015. Design of a twin capacitive load and its application to the outdoor rating of PV modules. Prog. Photovoltaics Res. Appl. John Wiley Sons 23, 247-252. doi:10.1002/pip.2425

Navarrete, M., Pérez, L., Domínguez, F., Castillo, G., Gómez, R., Martínez, M., Coello, J., Parra, V., 2015. On-site inspection of PV modules using an internationally accredited PV mobile lab: A three-year experience operating worldwide, in: 31st European Photovoltaic Solar Energy Conference and Exhibition. Hamburg, pp. 1989-1991. doi:10.4229/EUPVSEC201520155AV.6.19

Osterwald, C.R., Emery, K.A., Muller, M., 2014. Photovoltaic module calibration value versus optical air mass: the air mass function. Prog. Photovoltaics Res. Appl. 22, 560-573. doi:10.1002/pip.2303

Plag, F., Haas, F., Ramspeck, K., Nagel, H., Albert, H., Nevas, S., Sperfeld, P., Witt, F., Winter, S., 2014. Comprehensive analysis of a pulsed solar simulator to determine measurement uncertainty components, in: 29th European Photovoltaic Solar Energy Conference and Exhibition. Amsterdam, pp. 2435-2442. doi:10.4229/EUPVSEC20142014-5DO.9.2

PV MobiLAB. Kirchner Solar Group [WWW Document], 2012. URL http://www.kirchner-solargroup.de/pvmobilab/de/

Sandia, 2013. Sandia Module Database [WWW Document]. URL https://sam.nrel.gov/libraries

Solar simulators for PV modules, 2010. . Phot. Int. 210-241.

Solar simulators for PV modules includes new types of testers based on LED lamps, 2011. . Phot. Int. 200-234.

Whitfield, K., Osterwald, C.R., 2001. Procedure for Determining the Uncertainty of Photovoltaic Module Outdoor Electrical Performance. Prog. Photovoltaics Res. Appl. 9, 87-102. doi:10.1002/pip.356

Willians, S.R., Betts, T.R., Helf, T., Gottschalg, R., Beyer, H.G., Infield, D.G., 2003. Modelling longterm module performance based on realistic reporting conditions with consideration to spectral effects, in: 3rd World Conference on Photovoltaic Energy Conversion. Osaka, pp. 1908-1911. 